This item was submitted to Loughborough's Research Repository by the author.

Items in Figshare are protected by copyright, with all rights reserved, unless otherwise indicated.

\title{
Utility and non-state water service provision for the urban poor
}

PLEASE CITE THE PUBLISHED VERSION

http://dx.doi.org/10.1504/IJW.2008.019499

\section{PUBLISHER}

(c) Inderscience Enterprises Ltd.

\section{VERSION}

VoR (Version of Record)

\section{LICENCE}

CC BY-NC-ND 4.0

\section{REPOSITORY RECORD}

Sansom, Kevin, and Annette Bos. 2019. "Utility and Non-state Water Service Provision for the Urban Poor". figshare. https://hdl.handle.net/2134/9838. 
This item was submitted to Loughborough's Institutional Repository (https://dspace.lboro.ac.uk/) by the author and is made available under the following Creative Commons Licence conditions.

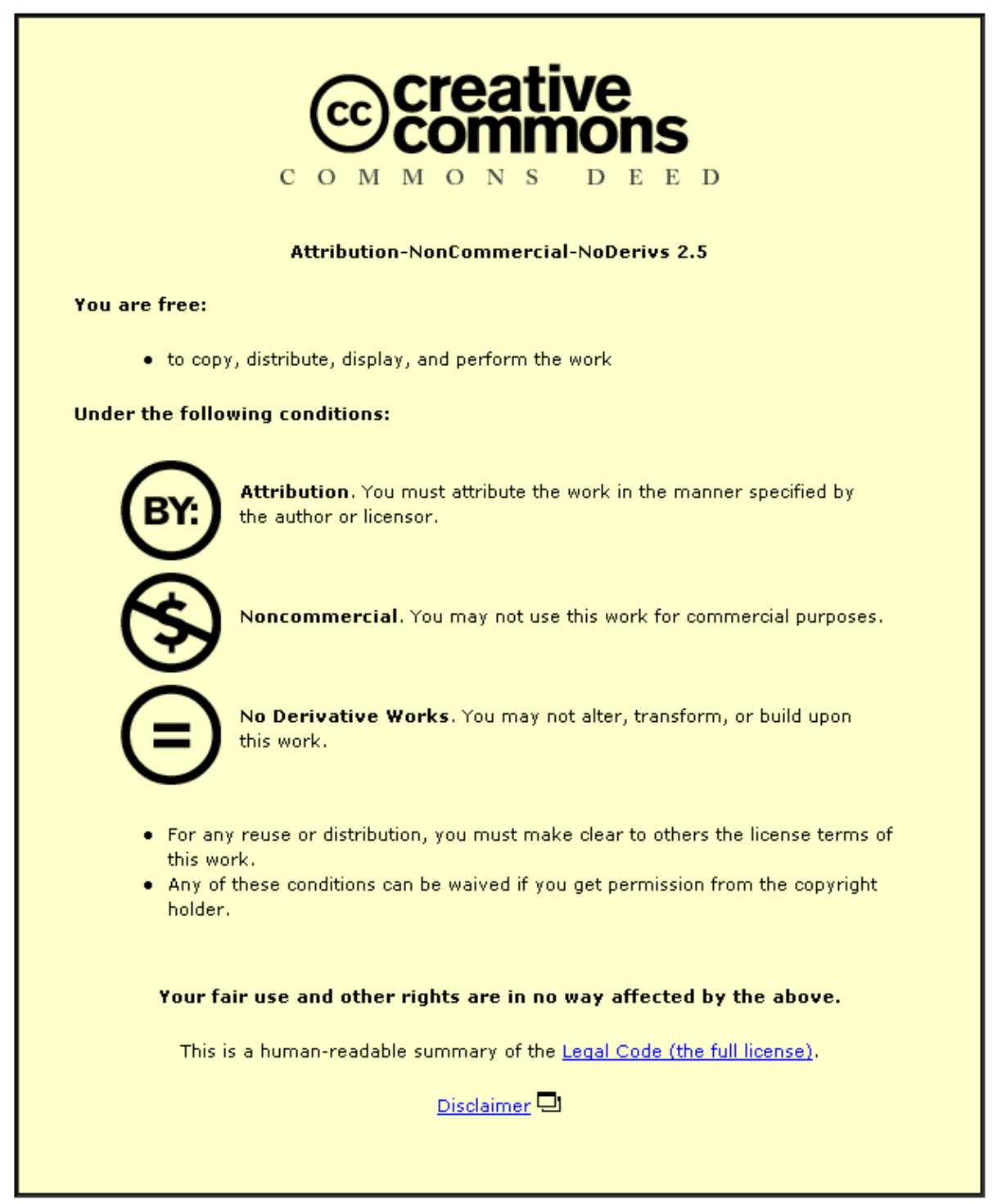

For the full text of this licence, please go to: http://creativecommons.org/licenses/by-nc-nd/2.5/ 


\title{
Utility and Non-State Water Service Provision for the Urban Poor
}

\section{Kevin Sansom}

WEDC, Loughborough University, Leicestershire, LE 11 3TU, United Kingdom, Phone: +44 (0)1509

222617 E-mail: k.r.sansom@lboro.ac.uk

\author{
Annette Bos \\ UNESCO-IHE Institute for Water Education. Department of Management and Institutions. \\ P.O. Box3015. 2601 DA Delft. The Netherlands. Phone: +-31-(0)15-2151770. \\ E-mail: a.bos@unesco-ihe.org
}

\begin{abstract}
Inadequate water service provision to the urban poor remains a serious problem in low income countries. Utilities lack the resources, obligations or incentives for service expansion and there may be a long delay before water utilities are in a position to extend services. Non-state water providers (NSPs), including both formal and informal local private providers, as well as civil society institutions, play a large role in provision of services to the urban poor and are increasingly recognised as a potential effective means of service provision to the urban poor. Governments should seek to create a better enabling environment for utilities to overcome disincentives in service provision to the poor and seek more effective ways of engagement with the NSPs.
\end{abstract}

\section{Keywords}

Water Utilities, Non-State Providers, Poor

\section{Introduction}

The historical justification for public sector involvement in water provision has been to ensure public health benefits, particularly for the poorest. However, the public water sector in low-income countries is also failing to meet the needs of the urban poor and in many cases has failed to achieve the goal of public health provision for the poor and has ended up subsidising the convenience interests of the rich. In the nineties there was the trend of increasing use of long term public private partnerships and it was widely argued that these large private operators would bring the capital for the much needed infrastructure to extend services to the poor. Experience shows that these partnerships have very mixed results and that they seem not more efficient in provision of services to the poor then the public sector (Prasad, 2006). Recent developments also show that the major multinational operators are not longer interested in the low income countries, where there is no guaranty for commercial viability of water services supply (Global Water Intelligence, 2005).

Provision of piped water supply to the poor by a formal utility may be desired and considered cost-effective in the long run (due to economies of scale and price).However, utilities lack the resources, obligations or incentives for service expansion and there may be a long delay before water utilities are in a position to extend services (Hunt and Tremolet, 2006). In meanwhile, it is increasingly recognised that local non-state providers (NSPs) including both formal and informal private providers, as well as civil society institutions, play a large role in water service provision to the urban poor. These NSPs have traditionally been assigned to illegality, because they are often considered a temporary solution that would need to be eliminated once the formal utility has developed sufficiently to expand its services in all areas (Hunt and Tremolet, 2006). 
In low-income countries both formal water utilities and NSPs have their comparative advantages and weaknesses in water services provision to the poor. In order to improve and make service provision affordable and to make best use of the scarce resources available, governments should seek to create a better enabling environment for utilities to overcome disincentives in service provision to the poor and seek more effective ways of engagement with the NSPs.

This paper briefly analysis why current public service provision to the poor is failing $^{1}$ and it outlines how some of these issues hampering service provision to the poor by the formal utility could be addressed. Given the importance of NSPs, the paper identifies the different forms of NSPs, it describes how effective forms of utility engagement can overcome disincentives in service provision to the poor by formal utilities, and expresses challenges in reaching the poor.

\section{Service provision to the poor by formal utilities}

Serving the urban poor with water requires the ability of a formal utility to deliver an inflexible, expensive, asset based service to a rapidly growing urban population of whom up to half are living at or below the poverty line, often in informal, 'illegal' housing areas. The water sector is facing this challenge of serving the urban poor in these difficult conditions. The poor performance of the public sector has been made worse by the rapid population growth in urban areas that would have stretched even the best water utilities. Average urban growth rates of 3.7 percent (POPIN, 2001) show that the urban population in middle and low-income countries have been doubling in less than twenty years. In some of the world's poorest countries half the population of cities are living below official poverty levels (UNFPA, 1996). Serving the poor is therefore a primary, not a secondary concern. This lies at the heart of the challenge of providing water in urban areas but progress towards provision of water services to the poor seem to be hampered. What are issues that create incentives or disincentives for direct government providers to improve service provision to the poor?

First issue: Often the direct provider has no mandate to serve the poor

A large percentage of the poor population lives in informal, illegal housing areas. The unplanned nature of such settlements makes it harder for direct providers to supply water through conventional means because of perceived constraints concerning land tenure, space to lay pipes and the poor's limited ability to pay. In addition, the law and regulations often necessitates a ban on government direct providers serving these illegal areas and, in doing so, regulation does not necessary provide a mandate to serve the poor.

An example can be found in Zambia where the government enacted a Water Supply and Sanitation Act in 1997. This Act provides for the regulation of commercial water supply and sanitation services in the country but it does not address the issue of universal coverage. In other words it does not mention service provision to low income areas. The national government of Uganda is partly to blame for the low service provision to the poor, as it owns the utility and provides a legislative framework for service delivery. Government expects the utility to "operate on sound commercial practice, and ensure that its revenues are sufficient to provide for (a) all depreciation, amortisation and interest rates; (b) all operation and maintenance costs;

\footnotetext{
${ }^{1}$ The findings are based on "Incentives for Water Utilities to serve the Urban Poor" a study undertaken by the Institutions and Managerial Working Group from the Water Supply and Sanitation Collaborative Council (Franceys and Bos eds, 2003)
} 
and (c) a reasonable return on investment”. The statute under which the utility operates does not consider the urban poor. Since the urban poor are presumed to have a low affordability to pay for the full cost recovery costs, the utility has in the past considered such households outside 'its official mandate'.

\section{Second issue: Creativity and innovativeness of service providers}

The private sector is assumed to be more creative and flexible than the public sector as they are under a much greater pressure to address the needs of the poor as this is stipulated in their contract. However, there are examples where public providers can be just as creative and innovative as private providers. Why are not all public utilities innovative in a solution to expand services to the poor? Publicly owned utilities, in their attempt to ensure the delivery of adequate services, have had to become ever more prescriptive in the standards that they expect, partly in an attempt to limit the temptations for officials to extract personal gain. As a result, middle managers know that they have to follow the rules and that obedience and submission to the technical standards is valued more highly than creativity and flexibility, particularly with regard to serving the illegal squatter areas. A recent study confirms that managerial autonomy is central to utility performance (Braadbaart, et al., 2006).

Clearly defined guidelines and stipulation of service provision responsibilities set out by government, and government grants to extend services to the poor can act as incentives. Proscriptive rules may require to be translated in to an acceptable, manageable and affordable level of service. In order for this to happen the direct provider needs a certain level of autonomy from government control and norms. This is to allow the utility to be creative and innovative in their attempts to serve the poor, to experiment and to fail before finding the right approach in a particular setting.

Third issue: The need for regulation by government.

Central governments have to provide the legal and economic framework, requiring the universal service obligation whilst enabling this provision through the implementation of realistic tariffs, for new connections as well as for consumption. Politicians, whether national or municipal, have to be enabled to understand that the poor are served more effectively through regular price rises which achieve overall cost reflective pricing (Shirley, 2000).

The government regulation in Santiago is fundamental for creating incentives to serve the poor. The well focused, government managed welfare subsidy provides this incentive, as tariffs for everyone, including the poor, are set on a realistic base (Komives, 2006). Also regular tariff increases do not necessary provide social problems for the poorer households as long as the subsidy scheme, set by government, helps to neutralise the tariff for the poorest.

\section{Fourth issue: Separation of direct provider and government}

Separation of the utility as the direct provider and the government as regulator is crucial for service extension to the poor. Incentives identified on the well focused, government managed welfare subsidy scheme in Santiago and the clear performance targets on increased service in Bolivia are real incentives because they are regulated and monitored by the regulator and implemented by, or with the help of, the direct provider. If government is in a poacher - gamekeeper situation then it will be very difficult to create incentives to serve the urban poor (Foster, 1996). 
Fifth issue: Price of water: Cross-subsidisation an incentive or disincentive?

Whether cross subsidisation or life-line block tariffs cater for the needs of the poor is subject to debate. The well intended social tariff systems can create undesirable effects or distortions. Although the economics of water provision show that, for a given capacity, cost per unit of water supplied declines as water use at any connection rises, increasing block tariffs invert this relationship for prices. The price charged per unit of water supplied therefore increases in a series of blocks of monthly consumption. As customers consume more water such that the total demand per month moves above a certain limit all additional water consumed is paid for at a higher price per cubic metre. The argument is that increasing block tariffs allow for a 'lifeline block', below the cost of supply, to ensure that basic water needs are affordable. The subsidy inherent in any lifeline block is then presumed to be paid for by the higher rate tariffs imposed on large users. This does not allow for the situation where poorer households, often in tenement or multi-occupancy housing, receive water through a single connection. In this situation, perversely, the poor end up paying more per unit of water than the higher-income groups (Komives, 1999).

The extremely low tariffs for water consumption by the poor can act as a substantial disincentive for utilities to extend services as tariffs often do not include all variable costs, including the cost of metering, billing and collection. This will contribute to an economic loss carried by the utility. As it is not cost effective for utilities to meter consumption that is highly subsidised or even bill them the utility loses the incentive to reduce the part of unaccounted for water related to commercial losses. As a result also water conservation is likely to be undermined. Yepes (Franceys and Bos, ed; 2003) argues that a highly differentiated tariff encourage corruption as users seek to be classified in a lower tariff group.

Whereas cross subsidies may provide disincentives to serve the poor well focused, government subsidies can provide clear incentives for utilities to do so. The bottom line is not to lose any revenue by serving the poor, as tariffs for everyone, including the poor, are set on a realistic base. This could mean that economic and operational issues have to be separated from social and distributive issues.

Sixth issue: Importance of contractual obligations including coverage targets.

Direct providers must have clear time-bound targets to achieve universal coverage (Tynan, 2000). A rewarding system should be established for stakeholders who are successful in reaching targets, whether they are public or private and there should be penalties for failing to achieve the target. The study on incentives to serve the poor shows an advantage that private providers have compared to public providers. The private providers have contractual incentives coupled with their motivation and willingness to be innovative and flexible in searching for ways to solve the provision problems. They have to solve these problems otherwise there will be penalties for failing to achieve the target and this will result in, for example, contract penalties / fines. Although a regulator stipulates responsibilities and what the contract should achieve it should not regulate how this should be done.

Although direct providers often fail in their provision to the poor, the poor still have to obtain water from somewhere, every day. This has been resolved in several ways - by neighbours on-selling water from their household taps, by vendors carrying water from distant standposts or illegal connections, and by tanker drivers sourcing from private boreholes or from illegally tapping the water mains. In these ways, local non-state providers (NSPs) have long been involved in meeting the water needs of the 
urban poor but being informal they have often been ignored. If formal utilities cannot overcome the resource constraints and disincentives outlined above, and given the large role NSPs play in service provision to the poor currently, then more effective ways of NSP engagement should be pursued.

\section{Types of Non-State Providers in the Water Sector}

A formal utility typically has a bulk supply and a limited water distribution network that do not reach many areas of a city/town and in particular the poor areas. Non-state providers (NSPs) provide water in these city/towns or neighbourhoods that are unserved or poorly served by the formal utility. NSPs in water services can be divided into three broad types that reflect the main types of activity undertaken, namely:

1. the informal private providers,

2. civil society organisations supporting community based management, and

3. private operators as part of public-private partnerships.

Each category tends to be very different in the types of service they deliver and in the characteristics and ethos of their organisations.

1. Informal private providers in the water sector.

In many low-income areas in Sub-Saharan Africa and Asia, people do not have their own utility piped water connection and rely on water obtained from NSPs. A study of ten cities in Africa (Collignon and Vézina, 2000) reported an average of 47 percent of households used small water providers or traditional sources such as dug wells, as their main sources of water. NSPs in a number of South East Asian cities serve between 20 to 45 percent of households (McIntosh, 2003). Water sector informal private providers can be divided into two distinct types: (WUP, 2003 and Moran and Batley, 2004)

- Independent Water Service Providers are not connected to the utility pipe network and may even compete with it. They generally obtain their water from alternative sources such as their own borewells, then distribute through a pipe network, or through carriers or a single supply point. Many independent providers are unauthorised or unregulated. Some of these independent service providers obtain water from unsafe sources such as unprotected springs and wells, which can present health risks for consumers.

- Intermediate Water Service Providers include private providers or community based organisations, delivering water in unserved areas. Intermediate providers generally obtain water from the utility piped network and either (i) install and manage network extensions or water points in unserved areas, or (ii) buy, carry and deliver water direct to customers willing to pay them (ibid). A wide variety of this type of NSP has emerged to fill specific market niches in urban water supply. They include: Resellers of home water (informal standpipes), standpipe or water kiosk operators, water carriers and carters, watertankers, and local sub-network providers. 


\section{Civil society organisations supporting community management}

A wide variety of civil society organisations operate in developing countries who are committed to participatory ways of working on water sector and/or multi-sector programmes including the following:

- International NGOs who tend to work with local NGOs and CBOs and often also engage in policy dialogue.

- Local NGOs in various forms such as faith based organisations and groups who have a particular ethos or defined ways of working; who usually work with CBOs and may engage in policy dialogue with government.

- Local NGO umbrella organisations who can enable networking, lesson learning and can provide a platform for advocacy or representing the views of CBOs.

- Community Based Organisations (CBOs) who seek to develop and perhaps manage water services in their communities in conjunction with other stakeholders such as NGOs and government, or they may do other activities on a self-help basis.

- CBO federations who can enable networking, lesson learning and can provide a platform for 'consumer voice'.

\section{Public Private Partnership contracts}

During the 1990s up to around 2002 there was a trend of increasing use of long-term public-private-partnership (PPP) contracts such as lease, and concession contracts for the management of urban water services in developing countries. This occurred in Latin America, Africa and East Asia. Many of the contracts have little or no provisions for serving the poor, which is a matter of concern to many stakeholders who question the priorities of the private operators. There have, however, been some good examples of private operators using participatory approaches, often together with NGOs, to serve low income areas with a range of service and payment options.

In the period 2000 to 2003 there were some high profile failures of large PPP contracts such as the concession contract in Buenos Aires, which occurred due to the local financial crisis. This has led the main private international operators in the water sector to be much less willing to take on the substantial commercial risks in low income countries. If there is to be less participation by the international private water operators in the long term management of urban water services in low income countries, then the local private sector, when enabled, is likely to play a larger role in the sector. Therefore the remaining of this paper focuses on government engagement of local private sector.

Well known examples of NSP's include ${ }^{2}$ : water kiosk or standpipe vendors which are managed by private sellers or community groups to sell water by the container. This is a convenient option for people who do not have a connection, although expensive because of the need to pay for somebody to sell the water by the container. Another good option for people who do not have a connection (provided that disputes can be managed) is selling piped water to neighbours from yard taps or flexible pipes. A private or community managed pipe network can often be found in informal

\footnotetext{
${ }^{2}$ Derived from Collignon and Vezina (2000) and Lyonnaise des Eaux (1998)
} 
settlements. This is a solution in areas where utility are not willing or able to work. Unit costs per volume are generally less than, for example, water bought by water trucks or tankers. These sell water to distributing vendors or direct to consumers and can be a suitable option where larger quantities of water are required for un-served areas. As indicated this is much more expensive than piped water. Another generally expensive option is the water carriers who carry water by hand, cycles or carts. They sell water directly to consumers at or near their homes. This is a suitable option where access is a problem.

\section{Utility Engagement with Non-State Water Service Providers}

As utilities are not able to serve the poor at present state there is significant scope for productive engagement between utilities and NSPs. This section outlines how effective NSP engagements can address issues that hampering service provision to the poor by the formal utilities.

Mandate, creativity and price

Although the informal water providers do not have the mandate to serve the poor areas they are especially inclined to proliferate in (un-serviced) informal areas due to there commercially oriented nature and the fact that they are less encumbered by bureaucracy than the public sector. In general terms, the informal private sector is more flexible in their operations and more responsive to consumer need. They respond to the needs of the market by accessing high population density communities through the provision of different service options (Collignon and Vezina, 2000). They have shown remarkable resourcefulness in finding simple, but effective, solutions often under the most adverse operating conditions (WSP, 2005)

However, also with provision through informal service providers the poor pay a price for this. In many places informal water providers face higher water tariffs than households with standard connections. Commercial tariffs are often higher than household tariffs, and increasing block tariffs punish households reselling water. Water tariffs often result in middle-income households with water connections paying less for water than do the vendors who supply low-income households (Kjellen and MCGranahan, 2006). If there is sufficient water being made available at the official tariff, and informal water providers are not cooperating to keep up the price of water, reducing water tariffs for informal water providers can be a straightforward means of assisting those who depend on these - often, among the poorest groups (Ibid).

NSPs with civil society organisations can have similar outputs in terms of mandate and creativity as the formal water providers and can deliver service where the formal utility is unable or unwilling to serve (DFID, 1995). In addition, they can be effective in participatory projects where community groups in poor urban areas are mobilised to contribute to the decision-making. This is often initially effective on water programmes and particularly true where the process is facilitated by an able intermediary such as an NGO. There are concerns, however, about the longer-term sustainable management of services including operations, maintenance and cost recovery of schemes run by civil society. In certain cases there seems to be a lack of incentives for community groups to continue with activities, particularly where the community groups are reliant on voluntary inputs from its members.

Schouten and Moriarty (2003) argue that community management needs an enabling framework of technical support, policies and laws in which to be implemented. Agreement on the distribution of roles between government, utility, community groups and other stakeholders is required to develop sustainable services. More 
sustainable arrangements often occur where the government or a utility has more of a direct contractual relationship with the community group and payments are made for services provided.

In assessing the comparative advantage of NSPs though informal providers there needs to be looked at the costs of service provision. In terms of value for money those service providers who expend the least time, expense and effort to transport a given quantity of water are generally the most cost effective. This invariably means that large piped water networks with high densities of paying customers tend to provide the most value for money. Public water utilities can support such informal private providers by extending the piped water network closer to the customers of the NSPs and providing suitable water collection points. These NSPs will then not need to transport their water so far and can reduce the prices charged to their customers.

\section{Separation of provider and government; contracts and regulation}

Separation of responsibilities between provider and regulator, through regulation and contracts, is likely to increase possibilities for provision of incentives to serve the poor. Where NSP services are procured through formal contracts they are usually able to respond better to incentives for improving performance because of their inherent flexibility and the competition incentives.

Different forms of NSPs require different types of contracts. Licensed water on sellers or standpipe public/private vendors have some form of contract and may operate standpipes built by government (see box 1). The contract may specify resale prices, hours of operation, terms of payment and conditions of rescinding the contract, although actual practices often deviate from the written terms (Kjellen and MCGranahan, 2006). The wholesale price (of water purchased by resellers from the utility) may be different from that of consumer households. In some places, resale prices are regulated, but difficult to control (Ibid).

\section{Box 1: Licensed standpipe operators in Ouagadougou (Burkina Faso) \\ Ouagadougou, Burkina Faso, has a network of close to 500 standpipes. Most of these are located in peri-urban areas and at the entry of unplanned settlements. They constitute an important source for the public, as there are few alternatives. In order to be selected to manage a standpipe, one must deposit CFAF 30,000 and sign a contract with the National Water and Sanitation Office (ONEA). Standpipe operators buy water for CFAF 187/m3 and sell it at CFAF $300 / \mathrm{m} 3$. Average monthly sales are in the area of CFAF 360,000, or 30-50 m3/day. Operations are closely supervised by ONEA, and any deviation from contract conditions can lead to the reassignment of the standpipe to another manager. There is an association of standpipe managers that seeks to bring common concerns to the attention of ONEA. Such concerns include improved transparency in the selection of standpipe managers.}

Source: Water Utility Partnership (2001-2003) Toolkit. A Practitioner's Companion. Case Examples: Standpipe Operators, Ouagadougou, Burkina Faso. (In: Kjellen and MCGranahan, 2006)

The regulation of smaller NSPs such as informal private providers and community groups in the water sector presents challenges due to their small scale and informal characteristics. NSPs such as water vendors often charge high water prices, so it is tempting for formal utilities to try and regulate their prices (economic regulation).

'Principal-Agent' theory examines organizational relationships as a tension between the 'principal' who demands a service and an 'agent' who provides it. The likelihood of the principal (such as the utility) effectively controlling an agent (such as an NSP) depends on: 
- how much information the principal has about the performance of the agent; and

- how far the principal can structure the relationship so as to make the agent's interests or objectives correspond to the principal's (Batley and Larbi, 2004)

In the case of regulation of a large private water utility, the principal is potentially able to effectively structure the relationship with the agent (operator) to achieve their objectives, through a carefully designed contract and good contract management. However, in the case of a utility that wishes to engage or control informal water providers, there is much less scope for the utility to control their work. This is because of the diverse, small and informal nature of the activities of NSPs such as water carriers. It would be impractical for a regulator to take into account the varying costs of a wide range of water NSPs in a city and then regulate those NSPs on a fair basis. Economic regulation of smaller informal NSPs is unlikely to be an efficient use of resources and it could even be counterproductive as standards are set too high, the net result could be smaller quantities of water with an even lower standard on a 'black market' (Kjellen and MCGranahan, 2006).

Other, more market friendly and supportive forms of regulation such as regulation minimum service quality levels, regulation of market entry, and publicising NSP performance and costs. For example, Tremolet and Browning (2002) propose making data on the performance of providers publicly available, thus relying on the regulating effects of reputation. For example, a utility or the regulator can publicise the price of water that the vendors pay at the location where they collect their water, so that customers can see the price mark-up when water is sold to them. This approach operates as a form of price regulation by making information about service performance transparent.

Although contractual arrangements between utilities and NSPs are starting to occur, there are many utilities that have yet to formally engage with NSPs. Recognising NSPs in provision of water services can build trust and accountability. Utility engagement could, for example, start by encouraging non-interference in acceptable NSP activities and having some limited formal recognition of NSPs. Interests of customers, NSPs and utilities may potentially be better resolved through open dialogue and official recognition of roles and responsibilities and it may also improve the legal protection of NSPs and their equipment against corrupt, discriminatory or arbitrary practices on behalf of different authorities (Kjellen and MCGranahan, 2006).If utilities want to support and enhance the services provided by NSPs and the public sector, then more substantial forms of engagement could be considered, such as registration of NSPs, and formal legal registrations to provide services. If these types of activities are done well, synergies can be achieved through collaboration between utility and NSPs. Successful utility/ NSP relationships often entail a number of different forms of engagement such as dialogue, collaboration, contracting and market friendly regulation.

\section{Challenges to reach the poor}

There are clear challenges for utilities intending to work with NSPs, even in more stable environments, not least of which is the institutional congruity between bureaucratic agencies and the more informal NSPs. In addition there is a challenge in the fact that utility engagement with NSPs can be perceived as contradicting. For utility to have a positive attitude towards NSPs might be seen as allowing a situation in which the poor pay the most. When utilitys have a negative outlook on NSPs, in 
particular the informal private providers) and enforce legislation, this could result in reduction of available water and higher the prices for the poorest segment of the population. (Kjellen and MCGranahan, 2006). It can also not be assumed that NSPs and/or utility staff want to engage with each other. Table 1 highlights such factors for that need to be considered when contemplating better engagement. As donors and governments seek to encourage public water sector agencies to engage more productively with different types of NSPs, they need to be mindful of the perceived incentives and disincentives that utility staff and NSPs may have.

Table 1 - Incentives for productive engagement with informal water NSPs

\begin{tabular}{|c|c|c|c|}
\hline \multicolumn{2}{|c|}{ Incentives for productive engagement } & \multicolumn{2}{|c|}{ Disincentives for productive engagement } \\
\hline NSP's perspective & Utility's perspective & NSP's perspective & $\begin{array}{l}\text { Utility staff's } \\
\text { perspective }\end{array}$ \\
\hline $\begin{array}{l}\text { 1. Formal recognition } \\
\text { and engagement can } \\
\text { provide some security } \\
\text { for the NSP's } \\
\text { operations and some } \\
\text { protection for their } \\
\text { investments. }\end{array}$ & $\begin{array}{l}\text { 1. Effective } \\
\text { collaboration can lead } \\
\text { to win-win agreements } \\
\text { that enable improved or } \\
\text { cheaper services for } \\
\text { consumers. }\end{array}$ & $\begin{array}{l}\text { 1. Formal recognition } \\
\text { and engagement with } \\
\text { utility could lead to } \\
\text { increased NSPs costs } \\
\text { such as taxes or new } \\
\text { technical requirements. }\end{array}$ & $\begin{array}{l}\text { 1. Utility staff are } \\
\text { often reluctant to } \\
\text { engage with informal } \\
\text { or illegal service } \\
\text { providers, who are } \\
\text { seen as unqualified } \\
\text { competitors. }\end{array}$ \\
\hline $\begin{array}{l}\text { 2. Opportunities for } \\
\text { expansion of NSP } \\
\text { services in conjunction } \\
\text { with utility. }\end{array}$ & $\begin{array}{l}\text { 2. If utility } \\
\text { facilitate/support } \\
\text { improved NSP services, } \\
\text { then they can claim } \\
\text { some of the credit. }\end{array}$ & $\begin{array}{l}\text { 2. Some Informal } \\
\text { NSPs may not have the } \\
\text { resources or skills to } \\
\text { meet utility } \\
\text { requirements. }\end{array}$ & $\begin{array}{l}\text { 2. Some staff may be } \\
\text { concerned about } \\
\text { reduced informal } \\
\text { payments that they } \\
\text { receive, if interactions } \\
\text { are more transparent. }\end{array}$ \\
\hline $\begin{array}{l}\text { 3. If NSPs are able to } \\
\text { improve their services } \\
\text { as a result of working } \\
\text { with utility, NSP } \\
\text { customers are likely to } \\
\text { be more satisfied and } \\
\text { loyal. }\end{array}$ & $\begin{array}{l}\text { 3. NSPs who use utility } \\
\text { water without paying } \\
\text { can be encouraged to } \\
\text { pay for their water. }\end{array}$ & $\begin{array}{l}\text { 3. In fragile states } \\
\text { NSPs may be reluctant } \\
\text { to engage with utility } \\
\text { for fear of getting } \\
\text { drawn into political } \\
\text { strife or conflict. }\end{array}$ & $\begin{array}{l}\text { 3. Engaging with so } \\
\text { many small informal } \\
\text { NSPs who have a } \\
\text { different work culture, } \\
\text { may not be considered } \\
\text { feasible. }\end{array}$ \\
\hline $\begin{array}{l}\text { 4. If some targeted } \\
\text { finance is provided by } \\
\text { utility or donors to } \\
\text { improve NSP services, } \\
\text { NSPs and their } \\
\text { customers can benefit. }\end{array}$ & $\begin{array}{l}\text { 4. Recognising and } \\
\text { working with NSPs } \\
\text { means that public } \\
\text { agencies can focus on } \\
\text { achievable public sector } \\
\text { service improvements. }\end{array}$ & & \\
\hline
\end{tabular}

Utility engagement with NSPs should be carefully guided. Where there is a shared understanding between utilities and NSPs about the working environment and incentives of both parties, there are much better prospects for effective partnerships and win-win situations emerging. Collignon and Plummer (2005) highlight a number of issues to be addressed to enable better utility engagement with local informal water private providers:

- Reconciling informality with conventional procedures. Most small operators are informal, impossible to contract, and difficult to monitor. Identifying mechanisms to overcome the incompatibility of informal business practice and formal procedures is essential if providers and utilities/municipalities are to work together. 
- Sharing the market. Water utilities typically capture the market through their monopoly status and officials are concerned that formal revenues and informal payments will decline with more recognition of local providers. Evidence in a number of utilities suggests however that bulk supply contracts with NSPs can result in win-win agreements with businesses and provide an incentive for both to share the market.

- Changing attitudes. Officials do not understand local private operators' working methods, the logic of their business or the rules of the informal market, and they do not have skills to work with these operators. Unsurprisingly there is often a deep mistrust between technocrats and the local entrepreneurs.

Similar challenges also apply to government working with civil society organisations which also are perceived to have an informal style of working.

\section{Conclusions}

In a resource limited situation in low income countries both formal utilities and NSPs have their comparative advantages and weaknesses in providing water services to the poor. At present formal utilities have no mandate or contractual obligations to serve the poor, they cannot be creative in serving the poor as there is a lack of managerial autonomy to search for appropriate solutions. Experience shows that governments play a large role in regulating meaningful subsidy schemes. Separation of the government and the service provider is necessary to prevent poacher - gamekeeper situations. Service provision by the formal utility may be desired (due to economies of scale), effective engagement between utility and NSPs is increasingly seen as a solution as NSPs are out there serving the poor and overcoming some of the obstacles faced by the formal utilities. However, this has a price. This price is paid by the poor!

Successful utility / NSP engagements can take different forms such as dialogue, collaboration, contracting and market friendly regulations. There are clear challenges that should be addressed while pursuing productive engagements between utilities and NSPs. Institutional congruity between bureaucratic and informal organisations provides a challenge as informality should be reconciled with conventional procedures. Utility staff and NSPs may have perceived incentives or disincentives what the engagement could bring them and this requires a change in attitude. Lastly, formal utilities should be willing to share their market, as formal revenues and informal payments may decline with the recognition of NSPs 


\section{References}

Batley, R. and Larbi, G. (2004) The Changing Role of Government: The Reform of Public Services in Developing Countries, Palgrave Macmillan, Hampshire.

Braadbaart, O., Eyebergen, N. and Hoffer, J. (2007) Managerial autonomy: does it matter for the performance of water utilities? Public Administration and Development, 27, 111-121.

Collignon, B. and Plummer, J. (2005) Supporting the market that serves the urban poor: Emerging responses to enhance the role of local private sector providers, Water and Utility and non-state water service provision, Sanitation Program, Background Paper for Workshop on Domestic Private Sector Participation Initiative, June, Nairobi.

Collignon, B and Vezina, M. (2000) Independent Water and Sanitation Providers in Africa Cities, Full Report of a Ten City Study, Water and Sanitation Program, Nairobi.

DFID (2005) Reducing Poverty by Tackling Social Exclusion, DFID policy paper, September, Department for International Development, London.

Foster, V. (1996) Policy Issues for the Water and Sanitation Sectors, IDB, Washington.

Franceys, R. and Bos, A. (ed., 2003) Incentives for Water Utilities to Serve the Urban Poor, Geneva: WSSCC, IMO Working group, Draft Report.

Global Water Intelligence (2005) 'Patience wins the day at Veolia', Global Water Intelligence, Vol. 6, No. 4, May. Available online at: www.globalwaterintel.com, (accessed on 25 August 2005).

Hunt, C. and Tremolet, S. (2006) Taking Account of the Poor in Water Sector Regulation, Water Supply \& Sanitation Working Notes Note No. 11, World Bank, Washington.

Kjellén, M. and McGranahan, G. (2006) Informal Water Vendors and the Urban Poor, Water Discussion Paper: Water-3, International Institute for Environment and Development, London.

Komives, K. (1999) Designing Pro-Poor Water and Sewer Concessions - Early Lessons from Bolivia, World Bank, Private Sector Development Department, Washington.

Komives, K., Halpern, J., Foster, V. and Wodon, Q. (2006) The Distributional Incidence of Residential Water and Electricity Subsidies, Research Working Paper 3878, World Bank, Washington.

Lyonnaise des Eaux (1998) 'Alternative solutions for water and sanitation in areas of limited financial resources’, Paris. 
McIntosh, A.C. (2003) Asian Water Supplies - Reaching the Poor, Asian

Development Bank, Manila and IWA Publishing, London.

Moran, D. and Batley, R.A. (2004) Literature Review of Non-State Providers of Basic Services, Available online at:

http://www.idd.bham.ac.uk/research/pdfs/Literature_Review_12April04.pdf

Prasad, N. (2006) Privatisation results: private sector participation in water services after 15 years, Development Policy Review, Vol. 24, No. 6, pp.669-692.

POPIN (2001) Population Information Network, World Urbanization Prospects: 1999 Revision, Population Division, Department of Economic and Social Affairs, United Nations, New York.

Sansom, K.R. (2006) 'Government engagement with non-state providers of water and sanitation services’, Public Administration and Development, Vol. 26, No. 3.

Schouten, T. and Moriarty, P. (2003) Community Water, Community Management From System to Service in Rural Areas, IRC, Delft and ITDG Publishing, London.

Shirley, M., Colin Xu, L. and Zuluaga, A. (2000) Reforming the Urban Water System in Santiago, Chile, Research Working Paper 2294, World Bank, Washington.

Tremolet S. and Browning, S. (2002) The interface between regulatory frameworks and partnerships - public, private and civil society partnerships providing water and sanitation partnerships to the poor, Business Partners for Development - BPD (Available online at: http://www.bpd-waterandsanitation.org).

Tynan, N. and Kingdom, W. (2002) Effective Water Service Provision, Second Draft, World Bank, Washington.

Water and Sanitation Programme (WSP) (2005) Understanding Small Scale Providers of Sanitation Services: A Case Study of Kibera, Fieldnote, June.

Water Utilities Partnership (WUP) (2003) Better water and sanitation for the urban poor, WUP for Capacity Building, Africa, Cote d'Ivoire.

WELL and DFID (2006) Briefing note on government engagement with urban informal water providers, WEDC, Loughborough University. 